\title{
DETEKSI MOLEKULER WHITE SPOT SYNDROME VIRUS (WSSV) \\ PADA UDANG VANAME (Litopenaeus vannamei) DI PT. HASFAM INTI SENTOSA
}

\author{
Miske Evi Gusti Yanti, Nurlaila Ervina Herliany, Bertoka FSP Negara, \\ Maya Angraini Fajar Utami \\ Program Studi IImu Kelautan Universitas Bengkulu \\ Email : miskeevigustiyanti@gmail.com
}

Received August 2017, Accepted September 2017

\begin{abstract}
ABSTRAK
Udang vanname (Litopenaeus vannamei) merupakan salah satu jenis udang yang umum dibudidayakan di Indonesia sejak pemerintahan mengeluarkan kebijakan untuk mengintroduksinya sebagai upaya menanggulangi penurunan produksi. Kehadiran udang vanname di Indonesia pada awalnya dapat diterima dan berkembang dengan baik oleh pembudidaya udang. Namun, produksi udang mengalami kemerosotan beberapa tahun terakhir seiring kemunculan penyaki. Virus disinyalir menjadi patogen paling berperan memicu penyakit pada udang. Tujuan dari penelitian ini adalah untuk mendeteksi keberadaan WSSV pada udang vanname (Litopenaeus vannamel) secara molekuler serta memperoleh keterkaitan antara kualitas air dengan keberadaan udang yang terinfeksi WSSV. Pengambilan sampel dilakukan di PT. Hasfam Inti Sentosa. Sampel di ambil secara acak dari 5 kolam yang berbeda pada hari ke 35 dan ke 70. Deteksi molekuler WSSV dilakukan di SKIPM Kelas II Bengkulu menggunakan Pockit Real Time PCR. Hasil identifikasi molekuler menunjukkan bahwa tidak terdapat virus WSSV atau negatif (-) WSSV pada udang yang berasal dari PT. Hasfam Inti Sentosa. Kualitas air secara keseluruhan optimal untuk budidaya udang vanname kecuali parameter ammonia dan nitrit. Tetapi parameter ammonia masih dalam batasan toleransi untuk udang vanname sehingga kualitas air tambak masih belum menyebabkan udang terinfeksi WSSV.
\end{abstract}

Kata Kunci : Deteksi molekuler, Tambak, Vanname, White Spot Syndrome Virus (WSSV).

\begin{abstract}
Vanname shrimp (Litopenaeus vannamei) is one of the most common shrimp species cultivated in Indonesia since the government issued a policy to introduce it as an effort to overcome the production decline. The
\end{abstract}


presence of Vanname shrimp in Indonesia was initially acceptable and well developed by the shrimp farmers. However, the shrimp production has declined in recent years caused by the appearance of the disease. Viruses are thought to be the most pathogenic trigger disease against the shrimp. The objectives of this research were to detect the presence of the White Spot Syndrome Virus (WSSV) in the Vanname shrimps (Litopenaeus vannamei) molecularly and to obtain the correlation between the quality of water with the presence of shrimps which infected by WSSV. The sampling technique of this research was done at PT. Hasfam Inti Sentosa. The sample was taken randomly from five different ponds on the $35^{\text {th }}$ and $70^{\text {th }}$ days. The molecular detection of WSSV was done at SKIPM Class II Bengkulu used Pockit Real Time PCR. The result of the molecular identification showed that there was no White Spot Syndrome Virus (WSSV) or negative (-) WSSV in the shrimp originating from PT. Hasfam Inti Sentosa. The overall water quality was optimal for vaname shrimp farming except for ammonia and nitrite parameters. However, the ammonia parameter for vanname shrimps were still within the limits of tolerance so that the pond water quality still has not caused the WSSV to infect the vanname shrimps.

Keywords: Molecular Detection, Shrimp, Vanname, White Spot Syndrome Virus (WSSV).

\section{PENDAHULUAN}

Udang vanname (Litopenaeus vannamei) merupakan salah satu jenis udang yang umum dibudidayakan di Indonesia sejak pemerintah mengeluarkan kebijakan untuk mengintroduksinya sebagai upaya menanggulangi penurunan produksi (KKP, 2001). Udang tersebut memiliki beberapa keunggulan dibandingkan udang penaeid lainnya seperti tingkat pertumbuhan yang lebih tinggi dan memungkinkan untuk dipelihara pada padat penebaran tinggi.

Kehadiran udang vanname di Indonesia pada awalnya dapat diterima dan berkembang dengan baik oleh pembudidaya udang. Namun, produksi udang kembali mengalami kemerosotan beberapa tahun terakhir seiring kemunculan penyakit. Virus disinyalir menjadi patogen paling berperan memicu penyakit pada udang. Setiap fase hidup dari udang vanname rentan diserang oleh infeksi virus yang mengakibatkan perubahan bentuk tubuh, ukuran benih yang tidak seragam, pertumbuhan yang lambat, hingga mortalitas (BBL Lampung, 2011). Salah satu penyebab utama penurunan produksi udang vanname tersebut adalah penyakit White Spot Syndrome Virus atau WSSV (Sukenda dkk., 2009).

WSSV adalah salah satu penyakit yang telah merambah secara global dan menjadi masalah serius pada sebagian besar spesies udang yang dibudidayakan secara komersil (Spann dan Lester, 1997). WSSV adalah virus DNA dengan bentuk seperti batang yang menyelubung dan nampak berpori (Wang et al., 1995; Lightner, 1996). Udang yang terinfeksi WSSV akan mengalami kematian mencapai $100 \%$ sehingga akan 
merugikan pembudidaya udang secara ekonomis dan akan berdampak negatif terhadap masyarakat yang mengkonsumsi udang yaitu mual, sakit perut (Supriatna, 2004).

Beberapa penelitian telah menginvestigasi keberadaan WSSV pada beberapa organ. (Kou dkk., 1998) melaporkan distribusi WSSV terdapat pada insang, kaki renang (pleiopod), kaki jalan (pereiopod), jantung, dan organ lainnya. Beberapa penelitian infeksi artifisial dengan analisis patogenik kuantitatif menunjukkan bahwa jaringan target major dari proses replikasi WSSV terdapat pada insang, lambung dan epitel kutikula tubuh, jaringan hematopoietik, organ limfoid dan kelenjar antenal (Tan dkk., 2001; Escobedo-Bonilla dkk., 2007).

Bengkulu merupakan salah satu propinsi yang kaya akan sumber daya alam, baik darat maupun laut. Dengan panjang garis pantai yang mencapai $525 \mathrm{~km}$ menjadikan propinsi ini kaya akan sumberdaya kelautan dan perikanan. Kualitas lingkungan yang baik menjadikan Bengkulu sebagai sentra budidaya udang super intensif baru di Sumatera BagianSelatan.Tercatat di Bengkulu telah berjalan enam perusahaan pembudidaya udang super intensif, salah satunya adalah PT. Hasfam Inti Sentosa. Berdasarkan hasil wawancara dengan ketua laboratorium tambak udang tersebut bahwasannya beberapa tahun yang lalu tambak sempat terindikasi terserang oleh virus WSSV sehingga ,dilakukakan pemberhentian produksi selama dua siklus. Sumber WSSV salah satunya berasal dari benur udang. Benur yang digunakan pada PT. Hasfam Inti Sentosa berasal dari luar provinsi sehingga untuk menjamin bahwa udang yang berasal dari tambak tersebut terbebas dari WSSV maka perlu dilakukan penelitian tentang "Deteksi Molekuler White Spot Syndrome Virus (WSSV) pada udang vaname (Litopenaeus vannamei) di PT. Hasfam Inti Sentosa".

Penelitian ini bekerjasama dengan Stasiun Karantina Ikan, Pengendalian Mutu dan Keamanan Hasil Perikanan Kelas II Bengkulu (SKIPM) sebagai salah satu Unit Pelaksana Teknis (UPT) Karantina Ikan Kementerian Kelautan dan Perikanan di daerah. SKIPM Kelas II Bengkulu memiliki peran menjaga kelestarian sumberdaya hayati di Propinsi Bengkulu sesuai dengan UU No. 16 Tahun 1992 dan PP No. 15 Tahun 2002, yaitu mencegah masuk dan tersebarnya hama dan penyakit ikan ke dalam wilayah Republik Indonesia, mencegah masuk dan tersebarnya hama dan penyakit ikan dari satu area ke area lain di dalam wilayah Republik Indonesia, serta mencegah keluarnya hama dan penyakit ikan dari wilayah Negara Republik Indonesia. Salah satu tugas SKIPM adalah mengecek kesehatan biota-biota yang akan masuk atau keluar dari Provinsi Bengkulu, salah satunya adalah udang.

\section{MATERI DAN METODE}

\section{Waktu dan Tempat Penelitian}

Penelitian dilakukan pada bulan April-Mei 2017 dan dilaksanakan di Stasiun Karantina Ikan, Pengendalian Mutu dan Keamanan Hasil 
Perikanan Kelas II Bengkulu. Sampel udang vanname diambil dari PT. Hasfam Inti Sentosa.

\section{Pengambilan Sampel}

Sampel yang digunakan dalam penelitian ini adalah udang vanname (Litopenaeus vannamei). Sampel diperoleh dari tambak PT. Hasfam Inti Sentosa. Sampel di ambil pada 5 kolam yang berbeda yaitu kolam A.6, A.7, A.8, A17 dan A.19. Pengambilan sampel menggunakan anco yang telah berisi pakan, kemudian anco diturunkan secara perlahan ke dasar kolam. Setelah beberapa menit, anco diangkat. Satu kolam diambil sebanyak 10 sampel. Sampel diambil pada umur 35 hari dan 70 hari. Selanjutnya sampel dibawa ke Laboratorium Uji SKIPM Kelas II Bengkulu untuk di analisis lebih lanjut.

\section{Identifikasi WSSV Pada Udang Vanname Secara Morfologi}

Analisa morfologi dilakukan untuk mengetahui ciri-ciri fisik udang vanname (Litopenaeus vannamei) yang terinfeksi WSSV. Analisa morfologi udang vanname (Litopenaeus vannamei) dilakukan di laboratorium Stasiun KIPM Kelas II Bengkulu menggunakan buku Penuntun Diagnosa Penyakit Ikan-II (Penyakit Ikan Laut dan Krustase di Indonesia) (Koesharyani, 2001).

\section{Analisa Kualitas Air}

Data kualitas air didapatkan dari data sekunder yang diperoleh dari laboratorium PT. Hasfam Inti Sentosa.

\section{Analisis Karakter Molekuler}

\section{Ekstraksi DNA}

Ekstraksi DNA dilakukan untuk memisahkan jaringan dan sel DNA pada sampel. DNA diekstrak dari sel-sel sampel untuk kemudian diamankan dari kerusakan akibat kerja enzim dNase. Ekstraksi DNA dilakukan menggunakan extraction kit. Jaringan yang telah halus direaksikan dengan reagen dari $I Q$ Plus Extraction Kit Selanjutnya ekstrak disentrifus sehingga diperoleh DNA yang akan dipakai dalam tahap kedua proses uji PCR. Hasil ekstraksi DNA pada tahap pertama kemudian digandakan (amplifikasi) (Parenrengi et al., 2009).

\section{Amplifikasi DNA}

Amplifikasi atau perbanyakan DNA dilakukan dengan mencampur DNA template (Isolat DNA sampel uji) dengan reagen dari IQ plus WSSV Kit. Amplifikasi DNA dilakukan dengan bantuan thermocycler atau yang lebih dikenal dengan alat PCR (Promega, 2007). 


\section{Pockit Real Time PCR}

Pockit Real Time PCR adalah suatu metode analisa yang dikembangkan dari reaksi PCR. Pockit Real Time PCR adalah suatu teknik pengerjaan PCR di laboratorium untuk pengamplifikasi (memperbanyak) sekaligus menghitung (kuantifikasi) jumlah target molekul DNA hasil amplifikasi tersebut (Fatimi, 2010).

\section{Analisa Data}

Data dijelaskan secara deskriptif untuk menggambarkan hasil penelitian yang diperoleh. Data yang diperoleh disajikan dalam bentuk gambar dan tabel untuk mendeskripsikan hasil penelitian.

\section{HASIL DAN PEMBAHASAN}

\section{Morfologi Sampel Udang Vanname}

Udang vanname yang didapatkan pada saat pengambilan sampel di tambak termasuk kedalam kategori udang yang sehat, tidak terdapat bercak putih pada karapas dan juga warna pada udang tersebut tidak mengalami perubahan (Gambar 1).

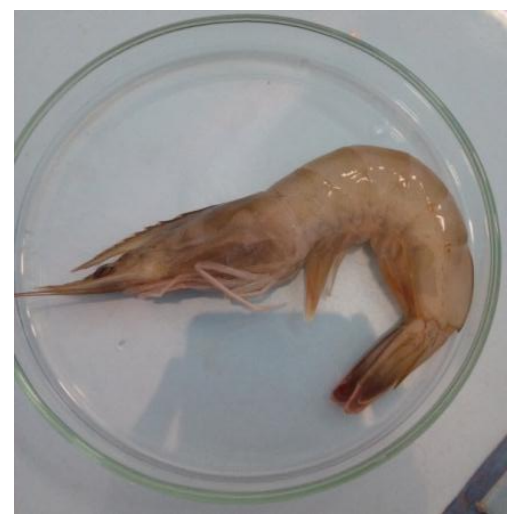

Gambar 1. Udang vanname sampel penelitian

Menurut buku Penuntun Diagnosa Penyakit Ikan-II (Penyakit Ikan Laut dan Krustase di Indonesia) (Koesharyani, 2001), gejala klinis yang dapat diketahui apabila sudah terinfeksi WSSV bisa terlihat seperti kehilangan nafsu makan, warna tubuh mejadi gelap, terdapat tanda bercak putih pada karapaks udang dan udang sering berenang ke permukaan (Gambar 2). Menurut Mahardika et al, (2004) udang yang terinfeksi WSSV akan mengalami perubahan tingkah laku yaitu menurunya aktivitas berenang, berenang tidak terarah, dan sering kali berenang pada salah satu sisinya saja. Selain itu udang cenderung bergerombol di tepi tambak dan berenang ke permukaan. Pada fase akut 
terdapat bercak-bercak putih pada karapas dengan diameter 0,5 - 3,0 $\mathrm{mm}$, dan bercak putih ini pertama kali muncul pada cephalothorak, segmen ke 5 dan ke 6 dari abdominal dan terakhir menyebar ke seluruh kutikula tubunya. Pada kasus WSSV adanya bintik atau spot putih pada bagian karapas sudah menjadi tanda umum, tetapi pada induk udang warnanya menjadi merah. Udang yang terserang penyakit ini dalam waktu singkat dapat mengalami kematian.

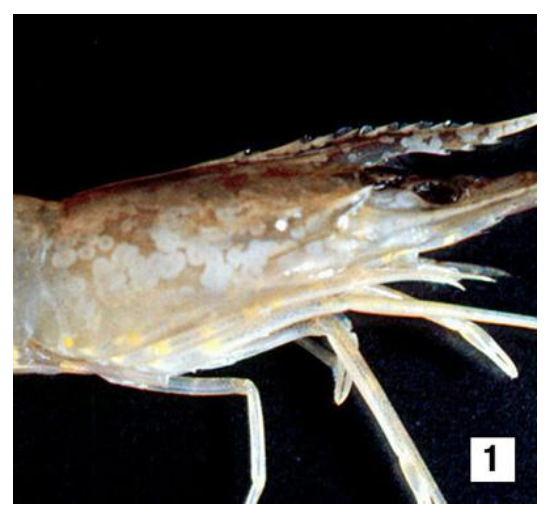

Gambar 2. Udang vanname terinfeksi WSSV

Sampai saat ini belum ditemukan cara pengobatan udang yang terinfeksi WSSV. Karena itu, sebaiknya udang yang baru didatangkan dari daerah lain, harus dikarantina dan bebas penyakit dengan cara pemeriksaan dengan PCR guna mencegah terjadinya penyebaran penyakit. Stres yang ditimbulkan selama pengangkutan juga menjadi pemicu terserangnya penyakit, sehingga perlunya meminimalkan stres selama pengangkutan dan menempatkan dalam lingkungan pemeliharaan yang baik.

\section{Analisa Molekuler}

Proses analisa molekuler udang vanname dilakukan melalui beberapa tahap yaitu tahap ekstraksi DNA dan amplifikasi DNA. Ukuran udang vanname yang digunakan adalah udang vanname yang berumur 35 hari dan 70 hari. Bagian yang digunakan dari udang ini adalah bagian hepatopankreas. Setelah proses atau tahap ekstraksi dan amplifikasi selesai dilakukan maka selanjutnya dilakukan proses Pockit Realtime PCR. Pockit Realtime PCR ini dapat menyimpulkan apakah sampel udang negatif (-) WSSV atau positif (+) terinfeksi WSSV.

Ekstraksi DNA dilakukan untuk memisahkan jaringan dan sel DNA pada sampel. Ekstraksi DNA ini merupakan tahap awal untuk penelitian yang dilakukan di lab uji SKIPM Kelas II Bengkulu. Ekstraksi DNA dilakukan langsung dibawah pengawasan menejer teknis laboratorium SKIPM Kelas II Bengkulu. Ekstraksi DNA dilakukan dengan cara pengambilan DNA dari sampel udang vanname, kemudian dimasukkan kedalam microtube yang telah disediakan. Sampel DNA yang didapatkan 
kemudian dicampur dengan reagen dari IQ Plus Extraction Kit. Ekstrak DNA yang didapatkan kemudian dilanjutkan dengan prosedur atau tahap selanjutnya, yaitu tahap amplifikasi DNA.

Amplifikasi DNA dilakukan untuk memperbanyak DNA dengan mencampur reagen dari IQ Plus WSSV Kit. Proses amplifikasi ini menggunakan primer yang sudah ditentukan sehingga membantu mempermudah proses pengerjaan amplifikasi. Hasil amplifikasi DNA yang telah didapatkan selanjutnya dianalisa menggunakan Pockit Real Time PCR. Sampel dimasukkan kedalam pockit dan tekan Run untuk memulai reaksi amplifikasi.

Hasil dari reaksi amplifikasi akan terlihat pada layar Pockit Real Time PCR setelah amplifikasi selesai atau sekitar 1 jam kemudian. Hasilnya dapat disimpan pada memori card POCKIT atau bisa didokumentasikan langsung menggunakan kamera. Setelah proses dokumentasi selesai tekan Buzzer Off pada menu, selanjutnya tekan power off di belakang instrument dan cabut kabel penghubung arus listrik.

Pada pockit real time PCR terdapat beberapa menu panjang gelombang yaitu sinyal $520 \mathrm{~nm}$, panjang gelombang $550 \mathrm{~nm}$ dan panjang gelombang $520 \mathrm{~nm}+550 \mathrm{~nm}$. Panjang gelombang $520 \mathrm{~nm}$ merupakan marker sinyal virus, apabila pada menu $520 \mathrm{~nm}$ terdapat tanda positif $(+)$ maka sampel tersebut positif (+) terinfeksi WSSV dan sebaliknya apabila pada panjang gelombang $520 \mathrm{~nm}$ terdapat tanda negatif (-) maka sampel tersebut tidak terinfeksi virus WSSV. Sinyal $550 \mathrm{~nm}$ yaitu internal kontrol, artinya sinyal $550 \mathrm{~nm}$ ini untuk mengetahui ada atau tidaknya genom DNA hasil ekstraksi hingga amplifikasi DNA yang telah dilakukan. Adanya tanda positif (+) pada menu $550 \mathrm{~nm}$ berarti ada genom DNA didalamnya sedangkan apabila pada menu $550 \mathrm{~nm}$ terdapat tanda negatif (-) berarti tidak terdapatnya genom DNA. Pada penelitian ini menggunakan menu panjang gelombang $520 \mathrm{~nm}+550 \mathrm{~nm}$. Adapun hasil dari Pockit Realtime PCR udang vaname dapat dilihat pada Gambar 3.

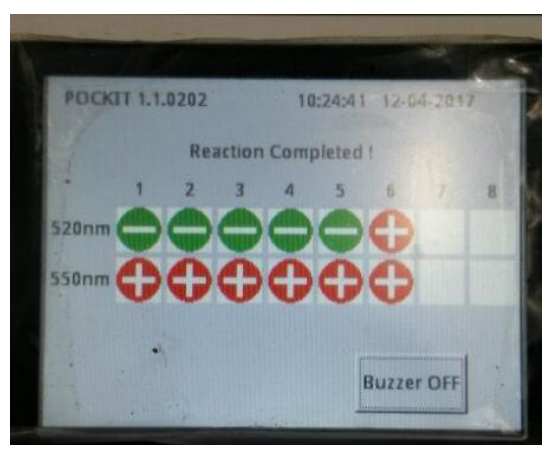

a

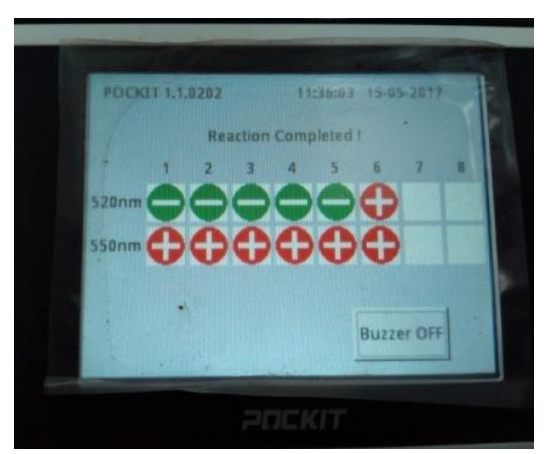

b

Gambar 3. (a) Hasil Pockit Realtime PCR sampel udang umur 35 hari

(b) hasil Pockit Realtime PCR sampel udang umur 70 hari 
Hasil pengujian WSSV melalui Molekuler WSSV menggunakan Pockit Realtime PCR dapat disimpulkan bahwa tidak terdapat WSSV atau negatif WSSV, dapat dilihat dari Gambar 5 dan 6 bahwa pada panjang gelombang $520 \mathrm{~nm}$ terdapat tanda negatif sehingga udang vanname terbebas dari virus WSSV. Hal ini diperkuat dengan adanya pernyataan dari instansi SKIPM Kelas II Bengkulu yang menyatakan bahwa udang vanname yang ada di tambak tersebut terbebas dari WSSV.

Tambak udang yang jadi objek penelitian terindikasi tidak mengalami infeksi WSSV baik melalui morfologi maupun melalui sampel DNA. Hal ini didukung oleh hasil analisa morfologi udang yang terinfeksi WSSV yang ditunjukkan tidak adanya terdapat ciri-ciri udang yang terinfeksi WSSV dan analisa Pockit Realtime PCR yang ditandai dengan tanda negatif (-) yang berarti tidak terinfeksi WSSV. Namun, apabila tambak udang positif (+) terinfeksi WSSV maka tambak tersebut harus ditutup selama dua siklus guna memperbaiki atau mensterilisasikan alatalat yang digunakan untuk budidaya udang.

Keberhasilan pengujian sampel dengan metode Pockit Realime PCR dipengaruhi oleh beberapa hal, seperti faktor kontaminasi silang, umur reagen atau enzim yang dipakai, jumlah enzim yang dipakai, ketelitian saat proses ektraksi dan amplifikasi, serta kondisi larutan buffer yang dipakai.

Keberhasilan budidaya udang ditentukan oleh kualitas induk dan benih, deteksi dini adanya penyakit dan skrining induk dan benur sebelum tebar adalah hal yang sangat penting dan harus dilakukan. Hanya induk sehat bebas virus yang dapat menghasilkan benur yang berkualitas dan lebih tahan penyakit. Menurut Sritunyalucksana et al. (2006), metode yang paling efektif mencegah kerugian akibat penyakit pada udang adalah dengan mencegah masuknya patogen ke dalam sistem budidaya. Pengawasan ketat pada prosedur-prosedur tersebut (deteksi dini, skrining induk, dan benur sebelum ditebar), serta ditambah pencegahan masuknya hewan yang menjadi "natural carrier" terbukti dapat mengurangi tingkat infeksi WSSV seperti yang berhasil dilakukan di Jepang. Saat ini, metode deteksi dini dan skrining induk, serta benih yang banyak digunakan adalah PCR (Lo et al., 1998). Metode berbasis molekuler ini menjadi pilihan karena sangat sensitif dan spesifik untuk mendeteksi virus penyebab penyakit pada udang.

Penyebab penyakit WSSV adalah virus SEMBV (Systemic Ectodermal and Mesodermal Baculo Virus). Virus ini merupakan virus berbahan genetik DNA (Dioxyribonucleic Acid), berbentuk batang (Baciliform). Organ yang terinfeksi virus yaitu kaki renang, kaki jalan, insang, lambung, otot abdomen, gonad, intestinum, karapas, jantung sehingga menimbulkan infeksi yang sistematik atau menyeluruh. Faktor pemicu timbulnya penyakit WSSV ini yaitu blooming fitoplankton kemudian mengalami kematian secara mendadak, kadar oksigen rendah, terjadi fluktuasi $\mathrm{pH}$ harian yang besar, rendahnya temperatur air, turun hujan secara mendadak dan pengelolaan yang kurang.

Pengendalian perluasan penyakit perlu dilakukan secara dini agar kerugian ekonomi tidak terjadi. Peningkatan kualitas benih udang 
vanname khususnya peningkatan ketahanan terhadap penyakit adalah hal yang sangat penting. Salah satu prosedur pencegahan penyakit di hatchery yang disarankan oleh Wang et al. (1998) adalah pemberian immunostimulan untuk meningkatkan daya tahan atau kekebalan alami benih terhadap penyakit.

Upaya penggunaan bahan kimia yang berlebihan dapat menimbulkan dampak bagi lingkungan perairan, kesehatan konsumen dan menimbulkan resistensi patogen (Alifuddin, 1998 dalam Fadli, 2000). Upaya-upaya yang dilakukan untuk menanggulangi masalah penyakit sudah dilakukan mulai dari screening formalin sampai pada penggunaan antibiotik, yang dilakukan pada kegiatan pembenihan sampai pembesaran. Tetapi pemakaian antibiotik secara terus menerus dan dosis yang tidak tepat akan mengakibatkan bakteri menjadi resisten (Lightner et al., 1992 dalam Zulham, 2004). Dampak lain dari pemberian antiobiotik adalah terakumulasinya antiobiotik dalam tubuh udang sehingga membahayakan konsumen. Untuk menghindari hal tersebut penggunaan bahan yang bersifat alamiah merupakan pilihan yang tepat. Suatu bahan alamiah yang mempunyai fungsi memperbaiki kondisi lingkungan dan sebagai immunostimulan bagi tubuh udang sangat diharapkan, sehingga tidak terjadi pemakaian beberapa macam obat yang berlebihan dan menyebabkan resisten bagi patogen.

\section{Kualitas Air}

Kualitas air tambak akan mempengaruhi proses metabolisme tubuh udang, seperti keaktifan mencari pakan, proses pencernaan, pertumbuhan dan perkembangan bagi udang. Data parameter kualitas air yang didapat dalam penelitian ini adalah: Salinitas, alkalinitas, ammonia, nitrit (Tabel 1).

Tabel 1. Kualitas air tambak budidaya udang vaname

\begin{tabular}{lllll}
\hline Kolam & $\begin{array}{l}\text { Salinitas } \\
(\mathrm{ppt})\end{array}$ & $\begin{array}{l}\text { Alkalinitas } \\
(\mathrm{ppm})\end{array}$ & $\begin{array}{l}\text { Ammonia } \\
(\mathrm{ppm})\end{array}$ & Nitrit $(\mathrm{mg} / \mathrm{L})$ \\
\hline A6 & $21-22$ & $132-144$ & 0,03 & 5 \\
A7 & $20-21$ & $136-156$ & $0,05-0,015$ & 5 \\
A8 & $20-21$ & $92-108$ & $0,1-0,27$ & 5 \\
A17 & $19-20$ & $112-152$ & $0,27-0,5$ & $1-5$ \\
A19 & $15-16$ & $96-122$ & $0,003-0,11$ & $0-1$ \\
\hline
\end{tabular}

Ket : data kualitas air diperoleh dari lab tambak budidaya udang vanname di PT. Hasfam Inti Sentosa. 


\section{Salinitas}

Salinitas yang diperoleh pada penelitian ini sesuai untuk budidaya udang vanname. PERMEN KP No 75 Th. 2016 menyatakan bahwa idealnya salinitas bagi budidaya udang antara 10 - 35 ppt. Salinitas merupakan faktor pembatas dalam perairan. Salinitas ini berhubungan langsung dengan sistem osmoregulasi udang (Wadidjah, 1998). Apabila salinitas tinggi, maka pertumbuhan udang akan melambat karena energi lebih banyak keserap untuk proses osmoregulasi dibandingkan untuk pertumbuhan (Kilawati dan Maimunah, 2014). Perubahan salinitas yang cepat dapat menyebabkan kematian udang yang tinggi (Tseng, 1987).

\section{Alkalinitas}

Alkalinitas pada tambak budidaya berkisar antara 96-156 ppm. Berdasarkan PERMEN KP no 75 th. 2016, persyaratan nilai alkalinitas untuk pemeliharaan udang vanname berkisar antara $100-150 \mathrm{mg} / \mathrm{l}$, sehingga alkalinitas tambak udang masih sesuai untuk budidaya udang vanname. Menurut Adiwijaya et al. (2003) alkalinitas yang optimal untuk kegiatan budidaya udang vanname berkisar antara 90-150 ppm. Apabila nilai alkalinitas diatas 150 ppm diperlukan pengenceran salinitas dan kepekatan plankton serta oksigenisasi yang cukup. Alkalinitas tinggi inilah yang membantu dalam menyediakan unsur kalsium untuk kebutuhan osmoregulasi sel dalam tubuh udang. Alkalinitas atau yang lebih dikenal dengan total alkalinitas adalah konsentrasi total dari unsur-unsur basa yang terkandung dalam air atau setara dengan kalsium karbonat ( $\mathrm{CaC03})$.

\section{Ammonia}

Konsentrasi ammonia di tambak yang melebihi batas optimal, dapat menghambat pertumbuhan udang sampai $50 \%$. Ammonia pada tambak budidaya berkisar antara 0,003-0,5 ppm. Agar udang tumbuh cukup baik, menurut PERMEN KP no 75 th. 2016 ammonia yang terdapat tidak boleh lebih dari $0,1 \mathrm{ppm}$. Berdasarkan hal tersebut ammonia pada tambak udang telah melebihi batas yang disarankan untuk budidaya udang. Tetapi, menurut Kumar et al. (2016) batas ammonia untuk udang vanname $<1 \mathrm{ppm}$. Pengaruh langsung dari kadar amonia yang tinggi tapi belum mematikan adalah rusaknya jaringan insang. Lembaran insang akan membengkak sehingga fungsi insang sebagai alat pernapasan akan terganggu dalam hal pengikatan oksigen dari air. Level amonia yang tinggi di perairan juga dapat meningkatkan konsentrasi amonia dalam darah sehingga mengurangi aktifitas darah (hemocyanin) dalam mengikat oksigen. Kadar ammonia berkaitan erat dengan $\mathrm{pH}$ air, apabila $\mathrm{pH}<7$ maka ammonia akan mengakibatkan ionisasi sedangkan apabila $\mathrm{pH}>7$ kadar ammonia di perairan akan lebih. Selain itu, tingginya kandungan ammonia disebabkan oleh padat penebaran tinggi. Jika padat penebaran tinggi maka kandungan ammonia juga akan semakin tinggi, hal ini disebabkan karena banyaknya buangan metabolit seperti feses maupun 
sisa pakan. Kualitas perairan dalam suatu perairan harus dikontrol terutama keberadaan ammonia karena akan mempengaruhi pertumbuhan udang, keberadaan ammonia yang tinggi akan dapat menimbulkan tumbuhnya penyakit dan tentunya akan menghambat pertumbuhan udang. Padat penebaran yang tinggi akan mengakibatkan penurunan pertumbuhan udang dalam budidaya, karena terbatasnya ruang gerak udang dan juga persaingan dalam memperebutkan makanan dan oksigen dalam perairan. Tingginya kandungan ammonia juga bisa berasal dari pakan yang tidak termakan oleh udang vanname sehingga larut dalam air.

\section{Nitrit}

Menurut PERMEN KP no 75 th. 2016, kandungan nitrit untuk pembesaran udang vanname adalah $\leq 1 \mathrm{mg} / \mathrm{L}$. Berdasarkan hal tersebut, maka kandungan nitrit di tambak lebih tinggi dan kurang sesuai untuk budidaya udang vanname. Kandungan nitrit tergantung pada jumlah ammonia, semakin tinggi jumlah ammonia, maka kandungan nitrit dalam perairan akan semakin meningkat. Penyebab tingginya kadar nitrit antara lain kepadatan yang terlalu tinggi sehingga banyak pembusukan dari kotoran atau feses maupun sisa pakan. Kadar nitrit ini sebaiknya dijaga pada kisaran normal untuk mengantisipasi tingkat kematian udang akibat keracunan nitrit.

Secara keseluruhan kualitas air tambak budidaya udang vaname yang terletak di PT. Hasfam Inti Sentosa sesuai untuk kehidupan udang vaname kecuali parameter ammonia dan nitrit. Kesehatan udang salah satunya dipengaruhi oleh kualitas air. Kualitas air yang baik mampu mendukung pertumbuhan secara optimal. Hal itu berhubungan dengan faktor stress udang akibat perubahan parameter kualitas air (Haliman dan Adijaya, 2006). Faktor pemicu munculnya penyakit pada udang tidak selalu disebabkan oleh munculnya organisme, faktor lingkungan seperti salinitas, kandungan $\mathrm{O} 2$, kadar amonia dan faktor kurangnya makanan juga menimbulkan stress pada udang (Amri, 2006). Faktor lingkungan ini mengakibatkan produksi antibodi berkurang sehingga imunitas atau kekebalan tubuh udang vaname terhadap serangan penyakit menjadi berkurang (Soetomo, 2000). Penyakit merupakan hasil interaksi yang tidak serasi antara lingkungan, inang, udang dan jasad organisme penyakit. Interaksi yang tidak seimbang ini menyebabkan stress pada udang, sehingga mekanisme pertahanan diri yang dimilikinya menjadi lemah akhirnya mudah diserang penyakit (Kordi, 2007). Hasil penelitian Kilawati dan Maimunah (2015) juga mengatakan bahwa kualitas air yang kurang baik dapat memicu munculnya virus. Hal ini diakibatkan oleh terjadinya gangguan pada tubuh udang misalnya gangguan osmoregulasi.

\section{KESIMPULAN}

Hasil identifikasi molekuler menunjukkan bahwa tidak terdapat virus WSSV atau negatif (-) WSSV pada udang yang berasal dari PT. Hasfam Inti Sentosa. Kualitas air secara keseluruhan optimal untuk budidaya 
udang vanname kecuali parameter ammonia dan nitrit. Tetapi parameter ammonia masih dalam batasan toleransi untuk udang vaname sehingga kualitas air tambak masih belum menyebabkan udang terinfeksi WSSV.

\section{DAFTAR PUSTAKA}

Adiwijaya D, Sapto PR, Sutikno E, Sugeng dan Subiyanto, 2003. Budidaya udang vaname (Litopenaeus vannamei) sistem tertutup yang ramah lingkungan. Departemen Kelautan dan Perikanan. Balai Besar Pengembangan Budidaya Air Payau Jepara. 29 hal.

Amri, K. 2006. Budi Daya Udang Windu Secara Intensif. Cetakan. 6. Agro Media Pustaka. Jakarta. 98 hal.

(BBL) Balai Budidaya Laut Lampung. 2011. Pengelolaan Kesehatan Ikan Budidaya Laut. Direktorat Jenderal Perikanan Budidaya, Departemen Kelautan dan Perikanan, Jakarta.

Escobedo-Bonilla, C.M., M. Wille, V. A. Sanz, P. Sorgeloos, M. B. Pensaert dan H. J. Nauwynck. 2007. Pathogenesis of a Thai Strain of White Spot Virus Syndrome (WSSV) in Juvenile, Specific Pathogen-Free Litopenaeus vannamei. Dis. Aquat. Org. Vol. 74: 8594.

Fadli, N. 2000. Evaluasi perlakuan pemberian immunostimulan terhadap larva udang windu (Panaeus moodon Fabr.) di Hatchery. Skripsi. Jurusan Budidaya Perairan, Fakultas Perikanan dan IImu Kelautan, IPB. Bogor.

Fatimi, 2010. Quantitative real time PCR for the measurement of WSSV in shrimp. J. Fish Dis. 25, 381-389.

Haliman, R.W., Adijaya D. 2006. Budidaya Udang Vannamei. Penebar Swadaya. Jakarta. 74 hal.

(KKP) Kementerian Kelautan dan Perikanan. 2001. Keputusan Menteri Kelautan dan Perikanan Nomor: KEP. 41/MEN/2001 tentang Pelepasan Varietas Udang Vaname sebagai Varietas Unggul.

Kilawati, Y. dan Y. Maimunah. 2014. Kualitas lingkungan tambak intensif litapenaeus vannamei dalam kaitannya dengan prevalensi penyakit white spot syndrome virus. Universitas Brawijaya. Malang. Research Journal Of Life Science 1 (2) : 2355-9926.

Kilawati, Y. dan Maimunah. Y. 2015, Kualitas Lingkungan Tambak Intensif Litapenaeus vannamei Dalam Kaitannya Dengan Prevalensi Penyakit White Spot Syndrome Virus. Research Journal Of Life Science, Universitas Brawijaya, Surabaya. Vol. 2. No. 1. Hal. 50 - 59. 
Koesharyani I., Reza, D., Mahardika K., Johnny, F., Zafran dan Yuasa. 2001. Penuntun Diagnosa Penyakit Ikan-II (Penyakit Ikan Laut dan Krustasea di Indonesia). Edisi II. Singaraja.

Kordi, M.G.H. dan A.B.Tancung. 2007. Pengelolaan Kualitas Air Dalam Budi Daya Perairan. Rineka Cipta. Jakarta.

Kou, G. H., S. E. Peng, Y. L. Chiudan C. F. Lo. 1998. Tissue distribution of white spot syndrome virus (WSSV) in shrimp and crabs. Flegel TW (ed) Advances in shrimp biotechnology. National Center for Genetic Engineering and Biotechnology, Bangkok.

Kumar, N. Srideepu, P. Reddy, H. Reddy, S. 2016. Effect of water probiotic (Pro-W) on Litopenaeus vannamei culture ponds of Nallore, Andhra Pradesh, India.

Lightner, D.V. 1996. A handbook of Shrimp Pathology and Diagnostic Procedure for Disease of Cultured Panaeid Shrimp. World Aquaculture Society, Lousiana. USA

Lo, C.F., Chang, Y.S., Cheng, C.T., dan Kou, G.H. (1998). PCR monitoring of cultured shrimp for white spot syndrome virus (WSSV) infection in growout ponds. In Flegel, T.W. (Ed.). advances in shrimp biotechnology. National Center for Genetic Engineering and Biotechnology, Bangkok.

Mahardika, K., Zafran dan I. Koesharyani. 2004. Deteksi White Spot Syndrome Virus (WSSV) Pada Udang Windu (Penaeus monodon) di Bali dan Jawa Timur Menggunakan Metode Polymerase Chain Reaction (PCR). Jurnal Penelitian Perikanan Indonesia, 10 (1): 5560.

Parenrengi, A., Shamsusin, L., Ismail, P., \& Amin, N.M. 2000. Preliminary study on DNA level marker of grouper at different buffer preservation and DNA extraction method. In: Saad, M.S., Faridah, Q.Z., Kadir, M.A., Khalid, M.Z.Z., Mohamad, O., Saleh, G.B., \& Panandam, J.M. (Eds.). Genetic Manipulation:Challenges and Advantages. Proceeding ofthe 4th National Congress on Genetics, 26- 28 September 2000, Genting Highlands, Malaysia, p. 194-208.

Promega. 2010. Technical Manual Wizard Genomic DNA Purification Kit. USA

Spann, K.M. dan R.J.G. Lester. 1997. Special topic review: Viral diseases of penaeid shrimp with particular reference to four viruses recently found in shrimp from Queensland. World journal of microbiology \& Biotechnology 13: 419-426.

Sritunyalucksana, K., J. Srisala, K. McColl, L. Nielson dan T.W. Flegel. 2006. Comparison of PCR testing methods for white spot syndrome 
virus (WSSV) infections in penaeid shrimp. Aquaculture, 255: 95104.

Sukenda, S. H. Dwinanti dan M. Yuhana. 2009. Keberadaan White Spot Syndrome Virus (WSSV), Taura Syndrome Virus (TSV) dan Infectious Hypodermal Haematopoitic Necrosis Virus (IHHNV) Di Tambak Intensif Udang Vaname Litopenaeus vannamei Di Bakauheni, Lampung Selatan. J. Akuakultur Indonesia Vol 8(2):1-8.

Soetomo, M. H. A. 2000. Teknik Budidaya Udang Windu. Sinar Baru Algensindo. Bandung

Supriatna. 2004. Deskripsi Penyakitlkan Bakterial (buku 15). Pusat KarantinaPertanian. 88 hal.

Tan, L.T., S. Soon, K.L. Lee, M. Shariff, M.D. Hassan, dan A.R. Omar. 2001. Quantitative analysis of an experimental white spot syndrome virus (WSSV) infection in Penaeus monodon Fabricus using competitive polymerase chain reaction. J. Fish. Dis. 24, 315-323.

Tseng WY. 1987. Shrimp Mariculture. Departement of Fisheries. University of Papua New Guinea. Port Moresby. Papua New Guinea.

Wadidjah, E. 1998. Pengaruh akumulasi bahan organik terhadap penyebaran udang windu ( $P$. monodon Fabr.) pada budidaya intensif. Skripsi. Jurusan Budidaya Perairan. Fakultas Perikanan dan Ilmu Kelautan. Institut Pertanian Bogor. Bogor.

Wang, Y. G., M. Shariff, P.M. Sudha, P.S. Srinivasa Rao. M.D. Hassan and L.T. Tan. 1998. Managing white spot disease in shrimp. Info Fish International, $\mathrm{p}:$ 30-36.

Wang, C.H., C.F. Lo, J.H. Leu, C.M. Chou, P.Y. Yeh, H.Y. Chou, M.C. Tung, C.F. Chang, M.S. Su dan G.H. Kou. 1995. Purification and Genomic Analysis of Baculovirus Associated With White Spot Syndrome (WSSV) of Penaeus monodon. Dis Aquat Org 23: 239242.

Zulham. R. 2004. Potensi ekstrak mangrove Sonneratia Caseolaris dan Avicennia marina untuk pengendalian bakteri vibrio harveyi pada larva udang windu (Panaeus monodon Fabr.). Fakultas Perikanan dan IImu Kelautan. Instit 